\title{
PERAN MODERASI SELF-ESTEEM PADA HUBUNGAN EMPLOYABILITY SKILLS DAN ADAPTABILITAS KARIER SISWA SMK
}

\author{
Dinda Aramitha Wahyu Safitri dan Wahyu Indianti \\ Fakultas Psikologi, Universitas Indonesia \\ Jl. Lkr. Kampus raya, Jl. Mawar No. 53 8, Kota Depok \\ Email: Dinda.aramitha@ui.ac.id
}

\begin{abstract}
ABSTRAK
Berkembangnya teknologi menyebabkan banyak perubahan, terutama pada masa pandemi saat ini di mana berdampak pada dunia industri. Individu yang memiliki adaptabilitas karier diprediksi memiliki kualitas pekerjaan yang baik sehingga dapat menghadapi berbagai tantangan karier. Employability skills dan self-esteem dianggap penting dalam memengaruhi adaptabilitas karier. Penelitian ini bertujuan untuk mengetahui peran self-esteem sebagai moderator hubungan employability skills dan adaptabilitas karier. Subjek penelitian ini terdiri dari 703 siswa SMK (usia 14-23 tahun). Alat ukur yang digunakan adalah Career Adapt-Abilities Scale $(\alpha=0,924)$, Student Employability Skills Questionnaire $(\alpha=0,939)$, dan Rosenberg's Self Esteem Scale $(\alpha=0,791)$ yang telah diadaptasi ke dalam bahasa indonesia. Hasil penelitian menunjukkan bahwa self-esteem tidak memoderasi hubungan employabilty skill dan adaptabilitas karier. Dengan kata lain, harga diri tidak memperkuat atau memperlemah hubungan keterampilan dasar kerja individu dan adaptabilitas karier. Hal tersebut karena employability skills memiliki pengaruh yang lebih kuat terhadap adaptabilitas karier sehingga tanpa adanya self-esteem tetap akan memberikan pengaruh terhadap adaptabilitas karier siswa.
\end{abstract}

Kata kunci: adaptabilitas karier; employability skills; self-esteem; siswa SMK.

\section{THE ROLE OF SELF-ESTEEM AS A MODERATION IN THE RELATIONSHIP OF EMPLOYABILITY SKILLS AND CAREER ADAPTABILITY ON VOCATIONAL STUDENTS}

\begin{abstract}
The evolution of technology give rise to a lot of change, moreover in this time of pandemic which influenced the industry. Individual who has an outstanding career adaptability predicted to have an outstanding work as well, hence could accomplished various career challenges. Employability skills and self-esteem considered important in influencing career adaptability. This study aims to study the effect of employability skills on career adaptability with the moderating role of self-esteem. The study was conducted on 703 vocational students (range of age 14-23 years old). Career Adapt-Abilities Scale $(\alpha=0,924)$, Student Employability skills Questionnaire $(\alpha=0,939)$, and Rosenberg's Self Esteem Scale $(\alpha=0,791)$, which already translated into Bahasa used to measured this study. The result shown that self-esteem was not moderating the effect of employability skills on career adaptability. In other words, self-esteem was not strengthen or weaken the effect of basic individual work skills on career adaptability. That is because employability skills have stronger influence towards career adaptability therefore even without selfesteem it will still give influence to student's career adaptability.
\end{abstract}

Keyword: career adaptability; employability skills; self-esteem; vocational students. 


\section{PENDAHULUAN}

Berkembangnya teknologi menyebabkan banyak perubahan, terutama di bidang industri dan dunia pekerjaan. Saat ini, ketika dunia memasuki era revolusi industri 4.0, pesatnya perkembangan teknologi memengaruhi berbagai perubahan pada disiplin ilmu, aktivitas industri, dan kapasitas tenaga kerja (Idris dalam Ramdhani, dkk, 2018). Pesatnya perkembangan teknologi membawa berbagai dampak positif maupun negatif dalam dunia kerja. Salah satu dampak positif dari berkembangnya teknologi adalah kemudahan dalam berinteraksi serta adanya cara baru dalam melakukan berbagai aktivitas. Dampak positif berkembangnya teknologi juga semakin dirasakan pada masa pandemi, di mana interaksi secara langsung harus dibatasi sehingga berbagai industri memanfaatkan perkembangan ini untuk memenuhi kebutuhan. Menurut Yudianto (2020), banyak industri yang mampu bertahan di masa pandemi karena memanfaatkan teknologi dengan penjualan dari e-commerce atau online.

Selain itu, berkembangnya teknologi juga dapat menggantikan berbagai jenis pekerjaan yang awalnya membutuhkan kekuatan fisik menjadi lebih mudah dengan adanya mesin-mesin otomatis (Wibowo, 2016). Akan tetapi, tergantikannya beberapa jenis pekerjaan dengan teknologi juga membawa dampak negatif, yaitu banyak pekerja yang akan kehilangan pekerjaan serta meningkatnya kebutuhan atas tenaga kerja terampil dan berkualitas (Wibowo, 2016). Banyak pekerjaan yang akan bergeser dari keterampilan membuat produk secara manual ke pekerjaan membuat produk dengan mengoperasikan mesin (Khurniawan dkk dalam Kemendikbud, 2017). Jenis pekerjaan yang memiliki kualifikasi keterampilan yang rendah atau berdasarkan Kualifikasi Keterampilan Nasional Indonesia (KKNI) berada pada level operator akan mudah tergantikan oleh teknologi sehingga lapangan pekerjaan pada level ini akan semakin sempit. Hilangnya beberapa jenis pekerjaan dengan kualifikasi rendah berdampak terhadap lulusan yang memiliki keterampilan yang rendah akan mengalami persaingan yang ketat. Hal ini dapat menjadi peluang bagi siswa Sekolah Menengah Kejuruan (SMK) sebagai tenaga kerja yang memiliki keterampilan khusus, namun jika siswa tidak mampu mengembangkan diri sehingga keterampilan yang dimiliki tidak sesuai dengan tuntutan dunia kerja maka akan semakin banyak menghasilkan pengangguran (Khurniawan dkk, dalam Kemendikbud, 2017). Padahal berdasarkan data Badan Pusat Statistik (2020) hingga Februari tahun ini, SMK masih menyumbangkan jumlah pengangguran tertinggi di antara jenjang pendidikan lainnya, yaitu sebesar 8,49 persen.

Terlebih lagi pada masa pandemi saat ini, kemungkinan angka pengangguran SMK dapat semakin meningkat. Peningkatan jumlah pengangguran tersebut karena siswa SMK tidak hanya dihadapkan dengan tuntutan untuk menjadi tenaga kerja yang terampil, tetapi juga kesulitan untuk mendapatkan kompetensi karier karena program magang atau praktik kerja lapangan (PKL) yang tertunda. Menurut Restubog (2020), adanya pandemi juga membuat siswa menghadapi kesempatan kerja dan magang yang langka atau terbatas sehingga kesulitan untuk memasuki dunia industri serta sulit memperoleh kompetensi karier. Kesulitan untuk mendapatkan kesempatan magang dan memasuki dunia industri dapat berdampak pada kepercayaan diri siswa untuk memantapkan penyesuaian kariernya. Situasi pandemi serta berkembangnya teknologi memang tidak dapat dihindari. Oleh karena itu, dibutuhkan kemampuan siswa untuk dapat beradaptasi terhadap berbagai tantangan, tuntutan serta transisi karir dengan mempersiapkan kariernya sejak awal. Menurut Hendrianti dan Dewinda (2019), kemampuan siswa dalam mempersiapkan karier sejak awal dapat membuat siswa bertahan melewati berbagai tantangan serta transisi karier.

Mempersiapkan karier merupakan tugas perkembangan yang harus diselesaikan. Beberapa peneliti menjelaskan bahwa salah satu tugas perkembangan remaja yang harus dipenuhi adalah memikirkan proses pemilihan karier yang dapat disesuaikan dengan minat, kepribadian, kapasitas diri, bakat, prospek masa depan pekerjaan, harapan, dan nilai yang mereka anut (Hirschi, 2009; Savickas, 2005; Sharf, 2006; Winkel \& Hastuti, 2004). Oleh karena itu, siswa SMK harus mengenali diri, baik kekurangan maupun kelebihan diri serta mengetahui tren pekerjaan yang ada di sekitarnya. Akan tetapi, berdasarkan beberapa hasil penelitian, siswa SMK masih bingung dalam mempersiapkan dan menentukan jalur arah karier pada masa depan karena kurangnya eksplorasi karier yang dilakukan (Istiqomah, 2016; Juwitaningrum, 2013). Selain itu, berdasarkan hasil survei singkat terhadap 67 siswa SMK yang dilakukan peneliti terdapat $46 \%$ siswa yang masuk SMK berdasarkan dorongan dari orang lain bukan diri sendiri. Hal tersebut 
menunjukkan bahwa keinginan masuk SMK bukan berasal dari dirinya sendiri dan terlihat siswa masih bingung dalam mempersiapkan kariernya sehingga memungkinkan salah menentukan jalur atau jurusan karier kedepannya. Padahal ketika masuk SMK, siswa sudah seharusnya mengetahui arah kariernya karena telah memilih sekolah dengan bidang keilmuan tertentu (Juwitaningrum, 2013).

Menurut Winkel dan Hastuti (2004), memilih program studi yang tidak sesuai pada tingkat pendidikan lanjutan atas dan pendidikan tinggi dapat berdampak terhadap rendahnya motivasi sehingga berujung pada prestasi akademik serta daya saing siswa yang rendah. Rendahnya prestasi akademik dan daya saing yang dimiliki siswa membuat ia kurang dapat bertahan ataupun beradapatasi dalam dunia kerja, terutama dalam situasi saat ini di mana kompetisi antar individu sangat ketat serta kesempatan kerja yang terbatas. Selain itu, keadaan ini dapat berefek negatif kepada kesejahteraan, kebahagiaan, dan kepuasan hidup individu (Indianti, 2015). Oleh karena itu, agar siswa mampu bersaing maka ia perlu menentukan arah karier selanjutnya serta menyesuaikan pilihannya dengan minat dan kompetensinya (Savickas, 2005; Sharf, 2006). Siswa perlu menentukan sejak awal, setelah lulus akan langsung bekerja, melanjutkan ke pendidikan tinggi, atau berwirausaha. Selain itu, siswa juga perlu menentukan bidang pekerjaan seperti apa yang akan ditekuni atau program studi apa yang akan dipilih pada pendidikan tinggi. Hal tersebut diperlukan agar ketika lulus, siswa SMK siap bersaing dengan jenjang pendidikan lain dan mampu mengatasi berbagai tantangan karena telah mengetahui tujuannya dan mempersiapkan diri. Menurut Savickas dan Porfeli (2012), proses perencanaan karier dan kemampuan untuk menghadapi tantangan serta transisi pada perkembangan karier merupakan bentuk dari adaptabilitas karier.

Adaptabilitas karier merupakan kekuatan dan kapasitas regulasi diri yang mungkin dapat digunakan saat menghadapi masalah yang asing, rumit, dan sulit berkaitan dengan tahapan perkembangan karier, transisi karier, dan trauma pada pekerjaan (Savickas \& Porfeli, 2012). Savickas yang merupakan pencetus teori adaptabilitas karier mengonseptualisasikan adaptabilitas karier sebagai struktur multidimensi yang terbagi menjadi empat komponen utama atau 4C, yaitu: concern, control, curiosity, dan confidence (Savickas \& Porfeli, 2012). Siswa yang memiliki concern atau kepedulian terhadap masa depan mampu membantunya mempersiapkan diri untuk hal yang akan terjadi selanjutnya. Kemudian, siswa yang memiliki control dapat bertanggung jawab untuk membentuk diri dan menyesuaikan diri terhadap lingkungan mereka serta dapat menghadapi apa yang terjadi selanjutnya dengan menggunakan kedisiplinan diri, upaya, dan ketekunan. Selanjutnya, curiosity dapat mendorong individu untuk berpikir tentang diri dalam berbagai situasi dan peran. Sedangkan, confidence merupakan keyakinan diri terkait dengan kemampuan untuk berhasil melaksanakan berbagai tindakan yang diperlukan dalam menetapkan pilihan pendidikan serta langkah selanjutnya yang sesuai (Savickas, 2005; Savickas \& Porfeli, 2012). Menurut Savickas \& Porfeli (2012), siswa yang mampu beradaptasi adalah mereka yang mampu menyelesaikan tugas perkembangan karier dan mengatasi transisi karier atau trauma pada karier. Oleh karena itu, dapat dikatakan adaptabilitas karier merupakan suatu kemampuan yang penting untuk dimiliki agar siswa mampu memenuhi berbagai tuntutan sehingga menjadi tenaga kerja yang terampil dan berkualitas.

Berdasarkan Pusat data Dan Teknologi Informasi Kemendikbud (2020), populasi siswa SMK di Indonesia pada tahun 2020 berjumlah 5,2 juta siswa lebih banyak dari siswa SMA yang hanya berjumlah 4,9 juta serta mengalami peningkatan lebih dari 1 juta siswa dalam periode 5 tahun. Besarnya peningkatan siswa SMK bila diiringi dengan kemampuan adaptabilitas karier yang baik diharapkan dapat menjadi bonus demografis untuk mendapatkan banyak calon tenaga kerja dari pendidikan menengah atas yang terampil secara profesional serta siap kerja. Hal tersebut sesuai dengan UU Sisdiknas No. 20 tahun 2003 yang menyatakan SMK memiliki tujuan khusus untuk menyiapkan siswa agar dapat produktif, mampu bekerja secara mandiri, dan mampu menjadi tenaga kerja tingkat menengah sesuai dengan kompetensi dalam program keahlian yang dipilihnya.

Kebutuhan industri dan dunia kerja akan tenaga kerja terampil serta berkualitas juga mendorong pemerintah untuk mempromosikan SMK sebagai pencetak tenaga kerja siap kerja dan mampu berpartisipasi dalam dunia kerja (Rosulin \& Paramita, 2015). Pemerintah menggencarkan program Revitalisasi Vokasional SMK dengan melakukan link and match serta pembinaan guru untuk meningkatkan kompetensi siswa SMK agar sesuai dengan kebutuhan industri (Setiawan, dalam Kemendikbud 2020). Program mencetak tenaga kerja siap kerja tersebut dilakukan untuk memenuhi kebutuhan industri yang hingga saat ini masih kekurangan tenaga kerja terampil. Menurut Menteri 
Ketenagakerjaan, Hanif Dhakiri (dalam Idhom, 2017), kebutuhan tenaga kerja terampil di Indonesia mencapai 113 juta pada tahun 2030 nanti, namun tenaga kerja di Indonesia baru berkisar 57 juta orang.

Selain upaya dari pemerintah untuk meningkatkan adaptabilitas karier siswa agar dapat menjadi tenaga kerja terampil dan berkualitas, dibutuhkan pula kemampuan dari dalam diri siswa untuk dapat meningkatkan adaptabilitas karier yang mereka miliki. Menurut Johnston (2018), terdapat beberapa faktor yang berkorelasi secara positif terhadap adaptabilitas karier, yaitu vocational identity status, employability skills, career aspirations, boundaryless mindset, career decidedness, dan career exploration. Kemudian, menurut Patton (dalam Maree, 2017), untuk dapat beradaptasi mengikuti perubahan dan dinamika yang terjadi di dunia kerja pada era teknologi dan pengetahuan saat ini, seorang pekerja harus memiliki berbagai keterampilan dasar yang menunjang pekerjaan. Hal tersebut karena industri saat ini tidak hanya mengharapkan lulusan memiliki pengetahuan dari bidang studi atau keahliannya saja, tetapi juga harus memiliki keterampilan dan sikap yang dapat digunakan untuk beradaptasi di lingkungan tempat ia bekerja (Rahmawati \& Komariah, 2016). Hal tersebut sejalan dengan pendapat Hanafi (2012) yang menyatakan bahwa industri tidak hanya mencari lulusan yang memiliki academic skills dan technical skills saja tetapi juga harus memiliki keterampilan dasar. Oleh karena itu, agar mampu melewati berbagai transisi karier para pekerja harus memiliki keterampilan dasar dan potensi yang dapat digunakan untuk mendapatkan dan sukses dalam pekerjaan atau disebut juga sebagai employability skills (Orji, 2013).

Menurut Cassidy (dalam Yahya dkk, 2017), employability skills merupakan keterampilan yang dapat digunakan atau diterapkan terhadap berbagai pekerjaan dan profesi. Employability skills juga memiliki beberapa istilah, yaitu employability capacities, transferable skills, graduate skills and attribute, dan generic skills yang istilahnya dapat digunakan secara bergantian (Brewer, 2013; Ismail dkk, 2016). Kemudian, Orji (2013) membagi employability skills menjadi beberapa keterampilan, seperti keterampilan komunikasi, problem-solving, team work, perencanaan dan pengorganisasian, kreativitas atau inovasi, independent study, keterampilan berhitung, ICT skills, manajemen diri, dan manajemen waktu. Individu yang memiliki employability skills, misalnya keterampilan problem solving, maka ia akan mampu mengatasi berbagai permasalahan maupun tantangan dalam karier. Kemampuannya dalam menyelesaikan berbagai masalah karier dapat membentuk atau meningkatkan kemampuan confidence yang merupakan salah satu dimensi dari adaptabilitas karier (Savickas \& Porfeli, 2012). Sedangkan, individu yang kurang memiliki employability skills, misalnya kurang baik dalam hal manjemen diri serta manajemen waktu, maka akan kesulitan untuk melakukan disiplin diri dalam membentuk diri untuk menyesuaikan dengan pilihan kariernya sehingga dimensi control yang dimiliki juga menjadi rendah. Menurut Savickas dan Porfeli (2012), individu yang kurang memiliki control dalam karier sering mengalami keraguan dalam memilih karier, bahkan menunda-nunda persiapan karier sehingga kurang dapat menentukan karier di masa depan (career indecision). Oleh karena itu, employability skills dianggap sangat penting bagi individu yang ingin masuk dan sukses dalam dunia kerja (Wibrow, dalam Rahman \& Wicaksono, 2018).

Selain itu, berdasarkan hasil survei singkat yang dilakukan oleh peneliti terkait "hal yang dapat menunjang karier" menunjukkan 59,7\% dari 67 siswa SMK menganggap pelatihan keterampilan sosial, seperti keterampilan berkomunikasi sebagai hal yang penting untuk menunjang kariernya pada masa depan. Melihat pentingnya employability skills, pemerintah juga memfokuskan beberapa program agar dapat meningkatkan keterampilan employability siswa SMK. Bahkan, pengembangan employability skills siswa menjadi tujuan utama pendidikan kejuruan di SMK (Khurniawan dkk dalam Kemendikbud, 2017). Menurut de Guzman dan Choi (2013), potensi dari employability skills telah dibuktikan mampu meningkatkan hasil pekerjaan dan membantu individu untuk beradaptasi serta meningkatkan peluang karier di tempat kerja. Selanjutnya, penelitian Ismail dkk (2016) menunjukkan adanya hubungan employability skills dan adaptabilitas karier dengan kekuatan hubungan yang besar. Selain itu, beberapa penelitian juga menunjukkan adanya hubungan yang signifikan secara positif antara employability skills dan adaptabilitas karier dengan kekuatan hubungan sedang (Akkermans, 2018; de Guzman dan Choi, 2013; Rocha, 2012). Beberapa hasil penelitian lain juga menunjukkan adanya hubungan yang signifikan antara employability skills dan adaptabilitas karier, namun dengan kekuatan hubungan yang cenderung lemah (Coetzee \& Engelbrecht, 2019; Nasruddin, 2019).

Beberapa hasil penelitian di atas menunjukkan adanya inkonsistensi kekuatan hubungan antara employability skills dan adaptabilitas karier. Oleh karena itu, dibutuhkan variabel lain yang dapat 
memperkuat hubungan antara kedua variabel tersebut. Menurut Johnston (2018) terdapat beberapa hasil penelitian longitudinal yang menunjukkan karakteristik individu sebagai prediktor adaptabilitas karier, yaitu proactive personality, self-esteem yang tinggi, dan career calling. Kemudian, hasil penelitian kualitatif Ozdemir (2019) menunjukkan penting untuk mengembangkan kepercayaan diri siswa terutama bagi siswa dengan adaptabilitas karier yang rendah. Hasil penelitian meta-analisis Rudolph dkk (2017) menunjukkan secara signifikan self-esteem merupakan salah satu indikator adaptivity dengan arah hubungan yang positif terhadap adaptabilitas karier karena siswa dengan self-esteem yang baik akan memiliki kepercayaan diri bahwa mereka dapat mengelola tugas dan mengatasi tantangan karier dengan sukses.

Selanjutnya, hasil survei pre-eliminary yang dilakukan oleh peneliti terkait "hal-hal apa yang membuat lulusan SMK sulit mendapatkan pekerjaan" menunjukkan bahwa ebanyak 23\% dari 67 siswa SMK mengatakan siswa SMK sudah dididik untuk siap bekerja dan memiliki keterampilan kerja yang lebih baik namun seringkali tidak yakin dengan potensi yang dimiliki. Siswa SMK juga merasa kalah saing dengan siswa SMA, merasa rendah diri karena hanya lulusan SMK, dan merasa perusahaan masih meragukan keterampilan yang mereka miliki. Pernyataan-pernyataan tersebut menunjukkan bahwa siswa SMK seringkali kurang yakin dan curiga terhadap harga dirinya sehingga kurang mampu menunjukkan keterampilan yang dimiliki serta kurang dapat mengevaluasi apa yang perlu ditingkatkn pada dirinya. Oleh karena itu, dapat diasumsikan ketika siswa memiliki harga diri atau self-esteem yang rendah meskipun sudah merasa memiliki keterampilan kerja maka adaptabilitas kariernya dapat menjadi rendah. Hal tersebut karena siswa dengan self-esteem yang rendah kesulitan untuk menunjukkan keterampilan yang ia miliki, tidak yakin dengan kemampuannya, dan kurang mampu mengembangkan diri sehingga kurang mampu untuk mengatasi berbagai tantangan karier. Sebaliknya, ketika siswa memiliki harga diri yang tinggi maka hubungan keterampilan kerja dengan adaptabilitas kariernya akan meningkat. Ketika ia memiliki self-esteem yang tinggi, ia dapat melihat kemampuan yang dimiliki, yakin terhadap kemampuannya, dan mampu mengevaluasi apa yang perlu diperbaiki sehingga dapat mudah untuk menyesuaikan diri dengan transisi serta mampu menghadapi berbagai tantangan karier.

Self-esteem atau harga diri didefinisikan sebagai persepsi individu terhadap diri sendiri, dalam bentuk positif ataupun negatif (Rosenberg dkk, 1995). Individu yang memiliki self-esteem tinggi cenderung mampu melihat kemampuan, pengaruh dan keberhargaan dirinya, di mana individu dengan self-esteem yang rendah sering meragukan kemampuan dirinya dan curiga terhadap harga dirinya (Cai dkk, 2014). Menurut Owens (1993 dalam Dacre Pool \& Sewell, 2007), individu yang memiliki selfesteem yang tinggi akan berpikir realistis dalam mengevaluasi dirinya sehingga ia akan memikirkan halhal yang dapat diperbaiki atau ditingkatkan dari dirinya. Sedangkan, individu yang memiliki self-esteem yang rendah akan menahan diri untuk berinteraksi dengan orang lain karena kurang percaya diri terhadap perilaku sosial yang mereka miliki (Zhao dkk dalam Ismail, dkk, 2016). Hal tersebut menunjukkan rendahnya self-esteem individu dapat berpengaruh terhadap salah satu dimensi adaptabilitas karier, yaitu confidence. Oleh karena itu, dari berbagai faktor yang dapat memengaruhi adaptabilitas karier diketahui bahwa self-esteem dapat memengaruhi hubungan keterampilan kerja atau employability skills yang dimiliki seseorang dengan kemampuan adaptabilitas kariernya untuk melewati berbagai transisi dan tantangan dalam karier. Hal tersebut membuat peneliti memilih self-esteem untuk dilihat peran moderasinya dalam hubungan employability skills dan adaptabilitas karier.

Hasil penelitian Ismail dkk (2016) juga menunjukkan bahwa self-esteem terbukti memoderasi hubungan graduateness skills attributes dengan adaptabilitas karier. Istilah graduateness skills attributes merujuk pada definisi yang sama dengan employability skills sehingga penggunaan istilahnya dapat digunakan secara bergantian (Brewer, 2013; Ismail dkk, 2016). Dalam penelitian Ismail dkk (2016) terdapat hasil yang menarik, yaitu self-esteem mampu memperkuat hubungan employability skills dan adaptabilitas karier, namun self-esteem tidak memperlemah hubungan employability skills dan adapatabilitas karier. Pada penelitian Ismail dkk (2016) tersebut ketika employability skills rendah, individu dengan skor self-esteem yang lebih tinggi memiliki skor adaptabilitas karier yang lebih rendah. Hasil penelitian tersebut menunjukkan pengaruh self-esteem yang tidak linear sebagai variabel moderator. Oleh karena itu, beberapa temuan penelitian di atas membuat peneliti tertarik untuk menguji kembali peran moderasi dari self esteem terhadap hubungan employability skills dan adapatbilitas karier pada siswa SMK. Hasil penelitian ini diharapkan dapat memperoleh gambaran peran self-esteem sebagai variabel moderator pada hubungan employability skills dan adaptabilitas karier siswa SMK. Gambaran 
tersebut nantinya dapat menjadi evaluasi dalam pengembangan program bimbingan karier siswa ke depannya.

\section{METODE}

Penelitian ini menggunakan pendekatan kuantitatif non-eksperimental berjenis cross-sectional study karena peneliti tidak memberikan manipulasi apapun terhadap variabel penelitian dan hanya melakukan sekali kontak dengan partisipan yang terlibat dalam penelitian ini. Desain penelitian ini digunakan untuk mengukur variabel adaptabilitas karier, employability skills, dan self-esteem. Partisipan dalam penelitian ini merupakan siswa Sekolah Menengah Kejuruan (SMK) di Indonesia dari tingkat satu hingga tingkat empat atau kelas 10 hingga 13. Jumlah partisipan sebanyak 355 orang siswa laki-laki dan 348 orang siswa perempuan $(n=703$ siswa) dengan rentang usia 14-23 tahun. Teknik pemilihan sampel yang digunakan adalah convenience atau accidental sampling. Proses pengambilan data dilakukan dengan menyebar kuesioner secara online melalui media sosial serta beberapa guru SMK yang peneliti kenal. Kuesioner ini disertai dengan informed consent yang menyatakan kesedian siswa untuk berpartisipasi dalam penelitian ini.

Pada tahap awal, peneliti melakukan studi literatur dan studi pendahuluan dengan melakukan survei kepada 67 siswa SMK di Indonesia terkait fenomena permasalahan yang dialami oleh siswa SMK. Kemudian, peneliti mencari alat ukur yang sesuai dan meminta izin terkait penggunaan instrumen pada penerjemah dan pengembang alat ukur versi Bahasa Indonesia. Setelah itu, peneliti memodifikasi beberapa kata agar sesuai untuk siswa SMK. Selanjutnya, melakukan proses expert judgement dengan tiga orang dosen Fakultas Psikologi Universitas Indonesia serta uji keterbacaan dengan sepuluh siswa SMK. Hal tersebut dilakukan untuk mengetahui validitas isi dari ketiga alat ukur tersebut sehingga dapat dikatakan bahwa ketiga alat ukur tersebut sudah valid mengukur konstruk yang hendak diukur. Peneliti juga mengajukan kaji etik untuk memastikan penelitian ini dapat diterima secara etis oleh masyarakat Indonesia.

Uji coba alat ukur dilakukan secara online dan didapatkan data sebanyak 98 responden siswa SMK. Berdasarkan hasil uji coba pertama, didapatkan reliabilitas sebesar 0,758-0,939, namun masih terdapat beberapa item yang memiliki nilai dibawah 0,30 sehingga perlu dilakukan analisis kualitatif. Peneliti memutuskan untuk merevisi item agar dapat dilakukan uji coba terpakai bersamaan dengan proses pengambilan data. Uji coba terpakai alat ukur adaptabilitas karier (CAAS) memiliki koefisien alpha sebesar 0,924, employability skills (SESQ) memiliki koefisien alpha sebesar 0,939, dan self-esteem (RSES) koefiesn alphanya sebesar 0,791. Akan tetapi, pada alat ukur self-esteem terdapat item, yaitu item 1 memiliki nilai crit di bawah 0,3 sehingga tidak dimasukkan ke dalam proses analisis lebih lanjut.

Proses pelaksanaan pengambilan data dilakukan pada tanggal 9 Oktober-1November 2020 pada siswa SMK. Pengambilan data dilakukan secara online menggunakan google form karena sekolah-sekolah masih memberlakukan Pembelajaran Jarak Jauh (PJJ). Peneliti berhasil mengumpulkan 761 data kuesioner. Kemudian, setelah diperiksa kelengkapan datanya dan kesesuaian karakteristik serta menghilangkan data outlier didapatkan sebanyak 703 data kuesioner.

Alat ukur adaptabilitas karier diadaptasi dari Career Adapt-Ability Scale (CAAS) yang dikembangkan oleh Savickas dan Porfeli (2012), kemudian diadaptasi ke dalam Bahasa Indonesia oleh Gunawan (2013). Alat ukur CAAS terdiri dari 24 item yang terbagi ke dalam empat dimensi. Alat ukur ini menggunakan skala Likert dengan lima kemungkinan jawaban. Kemudian, alat ukur employability skills yang digunakan diadaptasi dari alat ukur Student Employability Skills Quistionnaire (SESQ) yang dikembangkan oleh Orji (2013) dan diterjemahkan ke dalam bahasa indonesia oleh Rahman dan Wicaksono (2018). Alat ukur ini memiliki 32 item dan menggunakan skala Likert dengan lima kemungkinan jawaban. Alat ukur self-esteem yang digunakan pada penelitian ini diadaptasi dari alat ukur Rosenberg's Self-esteem Scale (RSES) yang dikembangkan oleh Rosenberg (1965). Skala yang digunakan merupakan skala yang telah diadaptasi ke dalam bahasa Indonesia oleh Syafris (2017). Alat ukur ini memiliki 10 item bersifat unidimensional atau hanya terdiri dari satu dimensi saja. yaitu selfesteem itu sendiri.

Selanjutnya, untuk teknik analisis peneliti melakukan analisis deskriptif meliputi perhitungan mean, nilai minimum, nilai maksimum, dan standar deviasi untuk mendapatkan gambaran responden dan persebaran variabel penelitian menggunakan program Statistical Package for the Social Science (SPSS). 
Kemudian sebelum menguji hipotesis, peneliti melakukan uji korelasi untuk mengetahui hubungan antar variabel menggunakan teknik Pearson Correlation. Selanjutnya, tujuan dari penelitian ini adalah untuk melihat peran self-esteem sebagai moderator dari pengaruh employability skills terhadap adaptabilitas karier pada siswa SMK. Oleh karena itu, peneliti melakukan analisis regresi linear dengan The Hayes Process Macro untuk menguji hipotesis penelitian, yaitu adanya efek moderasi self-esteem pada hubungan employability skills dan adaptabilitas karier siswa SMK.

\section{HASIL DAN PEMBAHASAN}

Partisipan penelitian ini berjumlah 703 siswa SMK yang berasal dari sekolah negeri maupun swasta di Indonesia. Gambaran demografis partisipan penelitian dapat dilihat dalam Tabel 1.

Tabel 1. Gambaran Demografis Partisipan Penelitian $(\mathrm{N}=703)$

\begin{tabular}{lcc}
\hline Karakteristik & $\mathbf{N}$ & $\mathbf{\%}$ \\
\hline Jenis Kelamin & & \\
Laki-laki & 355 & $50,5 \%$ \\
Perempuan & 348 & $49,5 \%$ \\
\hline Kelas & & \\
10 & 246 & $35 \%$ \\
11 & 173 & $24,6 \%$ \\
12 & 261 & $37,1 \%$ \\
13 & 23 & $3,3 \%$ \\
\hline Usia & & \\
$14-16$ & 363 & $51,6 \%$ \\
$17-20$ & 336 & $47,8 \%$ \\
$21-23$ & 4 & $0,5 \%$ \\
\hline Program Persiapan Karier & & \\
Ada & 385 & $56,2 \%$ \\
Tidak ada & 55 & $7,8 \%$ \\
Tidak tahu & 253 & $36 \%$ \\
\hline Pengalaman Bekerja & & \\
Belum Pernah & 454 & $64,6 \%$ \\
Pernah, Kerja Penuh Waktu & 19 & $2,7 \%$ \\
Pernah, magang & 178 & $25,3 \%$ \\
Pernah, Paruh waktu & 42 & $7,4 \%$ \\
\hline
\end{tabular}

Berdasarkan data demografis diketahui bahwa partisipan laki-laki mencapai 355 (50,5\%) dari total seluruh partisipan, jumlah partisipan menunjukkan proporsi yang cukup seimbang antara laki-laki dan perempuan. Partisipan paling banyak berada pada kelas 12 (37,1\%). Partisipan berada pada rentang usia 14-24 tahun. Jumlah pastisipan yang paling banyak berada pada rentang usia 14-16 tahun (51,6\%). Mayoritas partisipan (56,2\%) mengetahui adanya program persiapan karier di sekolahnya. Hal tersebut menunjukkan bahwa sebagaian besar sekolah sudah memiliki program persiapan karier serta siswa telah aware terhadap adanya program persiapan karier disekolahnya. Selain itu, terlihat lebih banyak jumlah partisipan yang belum pernah bekerja sama sekali, yaitu 454 orang $(64,6 \%)$ dibandingkan dengan jumlah partisipan yang sudah pernah bekerja sebanyak 239 orang $(35,4 \%)$.

Selanjutnya, analisis moderasi dilakukan untuk menguji asumsi penelitian, yaitu apakah selfesteem berperan sebagai moderator pada pengaruh employability skills terhadap adaptabilitas karier. Uji statistik model regresi tersebut dilakukan menggunakan program The Hayes Process Macro dalam aplikasi SPSS. Peneliti juga kembali memasukan variabel demografis sebagai covariate pada uji model regresi. 
Tabel 2. Kategorisasi Skor Partisipan Berdasarkan Norma Skala

\begin{tabular}{cccccc}
\hline Variabel & Mid point & \multicolumn{2}{c}{ Partisipan Kategori } & \multicolumn{2}{c}{ Partisipan Kategori } \\
& & \multicolumn{2}{c}{ Rendah } & \multicolumn{2}{c}{ Tinggi } \\
& & N & \% & N & \% \\
\hline Self-esteem & 2,5 & 348 & $49,5 \%$ & 355 & $50,5 \%$ \\
Employability skills & 2 & 344 & $48,9 \%$ & 359 & $51,1 \%$ \\
Adaptabilitas Karier & 2,5 & 330 & $46,9 \%$ & 373 & $53,1 \%$ \\
\hline
\end{tabular}

Berdasarkan tabel 2, hasil kategori skor variabel self-esteem, employability skills, dan adapatabilitas karier dilihat berdasarkan mid point alat ukur. Skor variabel self-esteem memiliki rentang 1-4 (skala Likert), untuk mendapatkan mid point maka nilai minimum dijumlahkan dengan nilai maksimum lalu dibagi 2 sehingga mendapatkan nilai mid point yaitu 2,5. Kemudian, variabel employability skills memiliki rentang 0-4 sehingga nilai mid point yang diperoleh sebesar 2. Selanjutnya, variabel adaptabilitas karier memiliki rentang 1-4 sehingga mid point bernilai sebesar 2,5. Oleh karena itu, dapat dikatakan secara umum partisipan pada penelitian ini memiliki self-esteem, employability skills, dan adaptabilitas karier yang tinggi karena nilai rata-ratanya lebih banyak berada di atas mid point.

Tabel 3. Hasil Efek Moderasi Self-esteem pada Hubungan Employability skills dan Adaptabilitas Karier

\begin{tabular}{|c|c|c|c|c|c|c|}
\hline Variabel & B-coeff & SE & t-stat & $p$-value & LLCI & ULCI \\
\hline \multicolumn{7}{|c|}{ Outcome Variable: Adaptabilitas Karier } \\
\hline Constant & 112,61 & 5,9 & 19,05 & 0,00 & 101,01 & 0,20 \\
\hline Employability skills $(\mathrm{X})$ & 0,45 & 0,02 & 21,31 & $0,00^{* *}$ & 0,41 & 0,49 \\
\hline Self esteem $(\mathrm{M})$ & 0,29 & 0,07 & 3,76 & $0,0002^{* *}$ & 0,14 & 0,45 \\
\hline $\begin{array}{l}\text { Employability skills } \mathrm{x} \text { self- } \\
\text { esteem (XM) }\end{array}$ & $-0,0005$ & 0,0039 & $-0,12$ & 0,89 & $-0,008$ & 0,007 \\
\hline Jenis kelamin & 0,64 & 0,73 & 0,87 & 0,38 & $-0,80$ & 2,08 \\
\hline Domisili & $-0,99$ & 0,15 & $-0,63$ & 0,52 & $-0,40$ & 0,20 \\
\hline Usia & $-0,45$ & 0,52 & $-0,08$ & 0,93 & $-1,08$ & 0,98 \\
\hline Kelas & $-1,58$ & 0,66 & $-2,36$ & $0,01 *$ & $-2,89$ & $-0,26$ \\
\hline Pengalaman kerja & 0,97 & 0,39 & 2,48 & $0,01 *$ & 0,20 & 1,75 \\
\hline Bimbingan karier & 0,43 & 0,40 & 1,07 & 0,28 & $-0,36$ & 1,22 \\
\hline \multicolumn{7}{|c|}{$\begin{array}{c}\mathrm{R}^{2}=0,473 ; \mathrm{MSE}=90,4 ; \mathrm{F}(9,693)=69,3 ; \mathrm{p}<0,001 \\
* p<0,05 ; * * p<0,01\end{array}$} \\
\hline
\end{tabular}

Berdasarkan tabel 3, dapat dilihat bahwa secara umum employability skills dan self-esteem secara signifikan bersama-sama memprediksi adaptabilitas karier, $\mathrm{F}(9,693)=69,3, p<0,01, \mathrm{R}^{2}=0,473$. Oleh karena itu, sebanyak 47,3\% varians dari adaptabilitas karier dapat dijelaskan oleh kedua prediktor tersebut. Kemudian, employability skills juga secara signifikan memprediksi adaptabilitas karier $(b=0,45$, $\mathrm{t}(703)=21,31, \mathrm{p}<0,01$, CI 95\% $[0,41,0,49])$. Hal ini dapat diinterpretasi bahwa setiap kenaikan 1 unit poin dari employability skills maka akan memprediksi peningkatan adaptabilitas karier sebesar 0,45. Peningkatan ini sesuai dengan landasan teori bahwa semakin besar employability skills yang dimiliki, semakin besar pula adaptabilitas kariernya (de Guzman \& Choi, 2013). Selanjutnya, self-esteem juga secara signifikan memprediksi adaptabilitas karier $(b=0,29, \mathrm{t}(703)=3,76, p<0,01, \mathrm{CI} 95 \%[0,14,0,45])$. Hal ini menunjukkan bahwa setiap kenaikan 1 unit poin dari self-estem, akan memprediksi peningkatan adaptabilitas karier sebesar 0,29.

Kemudian, tabel 3 juga menunjukkan bahwa ketika dijadikan sebagai covariate pada uji model regresi variabel kelas $(b=-1,58, t(703)=-2,36, p<0,05$, CI $95 \%[-2,89,-0,26])$ secara siginifikan berpengaruh terhadap adaptabilitas karier meskipun pada uji korelasi variabel kelas tidak memiliki hubungan yang signifikan dengan adaptabilitas karier. Nilai t-statistik sebesar -2,36 menunjukkan bahwa siswa yang berada di jenjang kelas lebih rendah memiliki skor adaptabilitas karier lebih tinggi. Kemudian, variabel demografis pengalaman bekerja $(b=0,97, t(703)=2,48, p<0,05$, CI 95\% [0,20, 1,75]) berpengaruh secara signifikan terhadap adaptabilitas karier (belum pernah $=1$; pernah bekerja fulltime $=2$; pernah bekerja magang $=3$; pernah bekerja paruh waktu $=4$ ). Hasil tersebut menunjukkan bahwa siswa yang telah memiliki pengalaman bekerja memiliki nilai adaptabilitas karier lebih tinggi. 
Selain itu, Tabel 3 juga menunjukkan bahwa efek interaksi employability skills dengan selfesteem $(b=-0,0005, t(703)=-0,12, p=0,89$, CI 95\% [-0,008, 0,0071]) secara statistik tidak signifikan memperkuat atau memperlemah adaptabilitas karier. Dengan demikian, dapat dikatakan tidak terdapat peran moderasi self-esteem pada hubungan employability skills dan adaptabilitas karier siswa SMK $(\mathrm{b}=-0,0005$, $\mathrm{p}=0,89$ ). Oleh karena itu, berdasarkan hasil tersebut maka hipotesis ditolak karena interaksi antara prediktor dan moderator tidak signifikan terhadap adaptabilitas karier.

Penelitian ini dilakukan untuk menguji peran self-esteem sebagai moderator pada hubungan employability skills dan adaptabilitas karier. Hal tersebut dilakukan karena terdapat inkonsistensi kekuatan hubungan antara employability skills dan adaptabilitas karier. Selain itu, berdasarkan hasil preeliminary study menunjukkan bahwa tinggi-rendah adaptabilitas karier siswa SMK juga dipengaruhi oleh self-esteem di mana banyak siswa yang merasa rendah diri, kurang mampu mengevaluasi diri, serta kurang yakin dengan kemampuannya meskipun sudah merasa memiliki keterampilan untuk bekerja. Selain itu, hasil penelitian Ismail dkk (2016) juga menunjukkan bahwa self-esteem mampu memoderasi hubungan graduatness skill atributes dengan adaptabilitas karier. Akan tetapi, hasil penelitian ini menunjukkan bahwa self-esteem tidak memoderasi pengaruh employability skills terhadap adaptabilitas karier. Hal tersebut karena employability skills sebagai prediktor adaptabilitas karier memiliki nilai prediktor yang lebih besar dari pada self-esteem. Dengan kata lain, employability skills memiliki pengaruh yang lebih kuat terhadap adaptabilitas karier sehingga tanpa adanya self-esteem tetap akan memberikan pengaruh terhadap adaptabilitas karier siswa. Siswa yang memiliki employability skills juga akan memiliki adaptabilitas karier tanpa bergantung dengan tingkat self-esteemnya. Misalnya, ketika siswa memiliki harga diri yang rendah, namun ia memiliki employability skills berupa problem solving dan team work yang baik maka ia akan tetap mampu mengatasi permasalahan karier yang terjadi. Hal tersebut karena ia memiliki kemampuan untuk bekerja sama dalam menyelesaikan suatu permasalahan atau memiliki ide-ide serta solusi yang dapat digunakan dalam penyelesaian masalah. Menurut Munadi dkk (dalam Kemendikbud, 2018), orang-orang yang siap bekerja serta memiliki employability skills atau keterampilan kerja yang baik dapat membantu mereka bertahan dalam lingkungan kerja karena mereka dapat diandalkan, bertanggung jawab, dapat memecahkan persoalaan, memiliki keterampilan sosial, dan mampu bekerja sama. Kemudian meskipun sedang menganggur, individu yang memiliki keterampilan kerja yang tinggi cenderung tetap mempertahankan self-esteem yang positif sehingga tidak terlalu merasa menderita (McArdle dkk, 2007).

Menurut Coopersmith (1967), self-esteem individu dipengaruhi oleh nilai dan aspirasi diri sehingga ketika individu mengganggap suatu keterampilan tidak penting atau tidak berkaitan dengan dirinya maka ketidakmampuan menguasai keterampilan atau rendahnya keterampilan yang dimiliki tersebut tidak memengaruhi harga diri atau self-esteemnya. Padahal ketika ia tidak menguasai salah satu keterampilan tersebut, ia menjadi kesulitan untuk menghadapi transisi serta tantangan dunia kerja. Oleh karena itu, meskipun self-esteem yang dimiliki positif, namun jika employability skillsnya rendah maka adaptabilitas kariernya akan tetap rendah. Melihat pentingnya employability skills terhadap adaptabilitas karier maka diperlukan pengembangan strategi pembelajaran untuk dapat meningkatkan employability skills siswa. Menurut Brewer (2013), strategi pengajaran, seperti presentasi, studi kasus, dan role play dapat mengembangkan employability skill yang berbeda. Kemudian, kesempatan belajar, seperti belajar mandiri, menghadiri pelatihan karir, atau program pembelajaran terintegrasi juga dapat meningkatkan employability skills (Jackson dalam Kornelakis \& Petrakaki, 2020). Selain itu, pengalaman berorganisasi juga dapat mempengaruhi employability skills individu (Rahman \& Wicaksono, 2018).

Selain itu, terdapat beberapa faktor lain yang juga memengaruhi adaptabilitas karier. Menurut Rudolph, dkk (2017), selain self-esteem, ia juga menemukan beberapa variabel yang terkait dengan adaptabilitas karier, yaitu cognitive ability, big five theory, core self-evaluation, proactive personality, future orientation, dispositional positivity (hope, optimisme), dan self-efficacy. Beberapa variabel lain tersebut tidak diperhitungkan pada penelitian ini sehingga peneliti tidak dapat mengontrol pengaruh variabel lain tersebut pada hubungan antara self-esteem, employability skills, dan adaptabilitas karier.

Selanjutnya, meskipun dalam penelitian ini self-esteem tidak signifikan berperan sebagai moderator, namun self-esteem siginifikan sebagai prediktor dari adaptabilitas karier pada siswa SMK. Sejalan dengan hal tersebut, beberapa hasil penelitian juga menunjukkan hasil serupa bahwa self-esteem berpengaruh secara positf terhadap adaptabilitas karier (Cai dkk, 2014; Atac dkk, 2017). Hal tersebut karena individu dengan self-esteem yang tinggi akan berpikir realistis dalam mengevaluasi dirinya 
sehingga ia akan memikirkan hal-hal yang dapat diperbaiki atau ditingkatkan dari dirinya (Owens dalam Darce Pool \& Sewell, 2007). Ketika individu mampu mengevaluasi diri dan memperbaiki kekurangan, ia akan mampu menyesuaikan diri dan beradaptasi dalam pekerjaannya. Oleh karena itu, penting bagi siswa untuk melakukan refleksi diri dengan baik agar dapat memahami kekuatan serta kelemahan yang ada pada diri.

Selain itu, berdasarkan analisis regresi menunjukkan employability skills dan self-esteem juga secara signifikan bersama-sama memprediksi adaptabilitas karier dengan sumbangan sebanyak 47,3\%. Dengan kata lain, employability skills dan self-esteem sama-sama mendukung adaptabilitas karier. Individu dengan employability skills yang baik serta self-esteem yang tinggi akan memiliki adaptabilitas karier yang lebih baik. Oleh karena itu, meskipun self-esteem tidak memoderasi hubungan employability skills dan adaptabilitas karier, namun self-esteem tetap perlu dipertimbangkan agar adaptabilitas karier siswa menjadi semakin baik.

Kemudian untuk analisis tambahan, ketika variabel demografis dijadikan covariate dalam uji analisis regresi menunjukkan bahwa variabel pengalaman kerja mampu memprediksi adaptabilitas karier secara positif. Hal tersebut dapat diartikan semakin banyak pengalaman kerja yang dimiliki, akan semakin tinggi adaptabilitas karier yang dimiliki. Sejalan dengan beberapa hasil penelitian terdahulu yang menyebutkan bahwa adaptabilitas karier berhubungan dengan pengalaman kerja yang dimiliki oleh individu (Patton \& Lokan, 2001; Santrock, 2016). Siswa yang memiliki pengalaman bekerja yang sesuai dengan minatnya dapat mengeksplorasi lebih dalam terkait pilihan kariernya sehingga memudahkan ia untuk merencanakan kariernya lebih matang. Selain itu, pengalaman kerja yang dimiliki siswa juga dapat mengembangkan employability skillsnya. Menurut Slameto (dalam Hakim \& Fitri, 2019), pengalaman kerja seperti Praktek Kerja Industri (PKL) juga merupakan faktor yang penting untuk menumbuhkam employability skills sehingga siswa memiliki kesiapan untuk terjun dalam dunia kerja atau menghadapi tantangan kerja. Akan tetapi, jika dilihat berdasarkan data partisipan, terlihat lebih banyak siswa $(64,6 \%)$ yang belum memiliki pengalaman bekerja dibandingkan dengan siswa yang sudah memiliki pengalaman bekerja (45,4\%). Padahal, siswa SMK wajib melakukan program magang selama minimal satu semester di industri dunia kerja (Denty \& Aline dalam Kemendikbud, 2020). Selain itu, berdasarkan tahap perkembangan karier Super (1970 dalam Zunker, 2012) individu pada usia 15-24 tahun biasanya sudah mulai memiliki pengalaman bekerja, meskipun belum memutuskan pilihan kariernya. Banyaknya partisipan yang belum memiliki pengalaman bekerja menunjukkan kurangnya perilaku eksplorasi karier siswa untuk dapat memahami pekerjaan atau jurusan yang akan dipilihnya nanti.

Kemudian, variabel jenjang kelas partisipan juga mampu memprediksi adaptabilitas karier secara signifikan dengan arah hubungan negatif. Dengan kata lain, semakin tinggi jenjang kelas partisipan maka akan semakin rendah nilai adaptabilitas karier yang dimiliki. Hal tersebut mungkin karena siswa kelas atas yang sudah merasakan dunia kerja dihadapkan pada situasi atau pengalaman yang lebih realistis dan banyak tekanan kerja sehingga adaptabilitas kariernya menjadi kurang adaptif serta kurang mampu menghadapi permasalahan. Sesuai dengan hasil penelitian Johnston, dkk (2013) bahwa adaptabilitas karier memiliki hubungan yang negatif dengan work stress. Perbedaan sikap serta pola pikir dalam melihat keadaan dunia industri mungkin juga dipengaruhi oleh banyaknya perubahan pada masa pandemi saat ini di mana siswa kelas atas dihadapkan pada kebingungan akan kesempatan dan peluang kerja yang menjadi semakin sulit. Menurut Restubog dkk (2020), adanya pandemi membuat siswa menghadapi kesempatan kerja dan magang yang langka atau terbatas sehingga kesulitan untuk memasuki dunia industri serta sulit memperoleh kompetensi karier. Oleh karena itu, tantangan karier yang dihadapi siswa kelas atas saat ini dapat menjadi work stress dan memengaruhi adaptabilitas kariernya menjadi lebih rendah. Selain itu, Patton dan Lokan (2001) juga menjelaskan bahwa terdapat perbedaan sikap dan pengetahuan antara siswa yang berada di kelas 9, 10, dan 11 meskipun pada skala kognitif tidak terdapat perbedaan, namun perbedaan sikap dan pengetahuan dapat memengaruhi adaptabilitas karier yang dimilikinya. Adaptabilitas karier juga dapat berubah dari waktu-kewaktu dengan adanya dukungan lingkungan, pengalaman, dan usia (Zacher dalam Pambudi, 2018).

Selanjutnya jika dilihat berdasarkan data partisipan, terlihat sudah banyak siswa $(56,2 \%)$ yang mengetahui adanya program bimbingan karier di sekolahnya. Meskipun secara umum sekolah sudah memiliki program persiapan karier, namun program pengembangan employability skills yang disasar oleh pemerintah baru mencakup keterampilan kreativitas dan produktivitas. Padahal masih terdapat keterampilan-keterampilan lain di dalam employability skills yang juga perlu dikembangkan. Selain itu, 
masih banyak pula siswa (36\%) yang tidak mengetahui apakah di sekolahnya terdapat bimbingan karier atau tidak. Hal tersebut menunjukkan rendahnya curiosity atau keingintahuan siswa dalam mengeskplor kariernya. Selain itu, terdapat $(7,8 \%)$ siswa yang mengatakan bahwa di sekolahnya tidak terdapat program bimbingan karier. Padahal hasil penelitian Jasmien (2016) menunjukkan bahwa semakin besar peran bimbingan karier, semakin tinggi adaptabilitas kariernya. Hal tersebut karena program bimbingan karier dapat membantu siswa untuk mengeksplorasi perkembangan kariernya. Oleh karena itu, penting bagi pihak sekolah untuk dapat mengadakan atau mengembangkan program persiapan karier agar siswa dapat lebih aware terhadap perkembangan kariernya.

Meskipun demikian, penelitian ini memiliki beberapa keterbatasan. Pertama, perencanaan teknis pada proses pengambilan data yang dilakukan secara online. Perencaanan teknis dalam penelitian ini masih perlu ditingkatkan agar dapat lebih memudahkan peneliti dalam melakukan screening partisipan. Terlebih lagi, peneliti kurang dapat mengontrol partisipan yang mengisi kuesioner online secara langsung sehingga diperlukan perencanaan yang lebih terstruktur dan tertib. Misalnya, meminta partisipan untuk memasukan alamat email ataupun nomor telepon agar memudahkan peneliti dalam melakukan pengecekan data ganda. Peneliti selanjutnya juga dapat menggunakan platform kuesioner online yang mampu mengenali IP address dari gawai yang digunakan partisipan untuk mengisi kuesioner sehingga menghindari adanya data ganda. Selain itu, peneliti juga perlu meningkatkan keamanan platform agar data partisipan dapat lebih terjaga kerahasiannya. Kedua, pengukuran employability skills pada penelitian ini dilakukan menggunakan self-report, yaitu berupa persepsi siswa terkait kemampuannya sehingga kurang dapat menunjukkan performa aktual terkait employability yang dimiliki oleh siswa. Menurut Jonsson (dalam Suarta dkk, 2015), asesmen kinerja atau performance assesment dapat memberikan data yang lebih valid tentang kompetensi siswa. Hal tersebut karena pada performance assesment siswa diminta untuk mendemonstrasikan kemampuannya sehingga dapat terlihat kompetensinya. Peneliti tidak menggunakan pengukuran performance dengan pertimbangan keterbatasan waktu dan tenaga dalam melakukan penelitian. Selain itu, dibutuhkan objektivitas yang tinggi untuk menilai performance partisipan.

\section{SIMPULAN}

Penelitian ini dilakukan untuk menguji peran self-esteem sebagai moderator antara pengaruh employabilty skill terhadap adaptabilitas karier pada siswa SMK. Uji moderasi menunjukkan bahwa selfesteem tidak memoderasi hubungan employabilty skill dan adaptabilitas karier. Dengan kata lain, selfesteem atau harga diri tidak memperkuat atau memperlemah hubungan employabilty skill dan adaptabilitas karier. Oleh karena itu, hipotesis penelitian ditolak.

Berdasarkan temuan dan keterbatasan penelitian diatas, terdapat saran untuk penelitian berikutnya. Melihat hasil penelitian yang menunjukkan adanya pengaruh kelas dan pengalaman kerja siswa dimana variabel kelas memengaruhi adaptabilitas karier secara negatif, sedangkan pengalaman kerja memengaruhi adaptabilitas karier secara positif. Berdasarkan hal tersebut, dapat diasumsikan siswa pada kelas atas yang sudah merasakan dunia kerja dihadapkan pada situasi atau pengalaman yang lebih realistis dan apabila tidak memiliki pengalaman kerja yang baik akan menjadi work stress tersendiri bagi siswa sehingga dapat memengaruhi adaptabilitas kariernya. Pengalaman kerja yang relevan juga memengaruhi employability skills yang dimiliki siswa. Oleh karena itu, peneliti selanjutnya dapat melakukan uji peran work stress, pengalaman bekerja, dan employability skills terhadap adaptabilitas karier siswa.

Selanjutnya, meskipun dalam penelitian ini tidak terbukti bahwa self-esteem berperan sebagai moderator pada pengaruh employability skills terhadap adaptabilitas karier, namun self-esteem dan employability skills terbukti secara signifikan berpengaruh terhadap adaptabilitas karier sehingga pemerintah, siswa, dan guru juga perlu memperhatikan self-esteem dan employability skills yang dimiliki oleh siswa. Bagi pemerintah khususnya Direktorat Sekolah Menengah Kejuruan Kementerian Pendidikan dan Kebudayaan agar dapat memfasilitasi pelatihan ataupun seminar secara daring maupun luring terkait pengembangan employability skills siswa SMK. Bagi sekolah ataupun pendidik perlu meningkatkan strategi pembelajaran yang berpengaruh terhadap pengembangan employability skills siswa. Selanjutnya, sekolah juga dapat melaksanakan atau meningkatkan layanan bimbingan ataupun konseling karier dan mengadakan pelatihan yang sesuai dengan kebutuhan siswa. Bagi siswa dapat aktif mengikuti berbagai 
kegiatan organisasi yang ada di dalam atau pun di luar sekolah agar dapat meningkatkan employability skills pada siswa. Kemudian, siswa juga dapat melakukan kegiatan eksplorasi karier yang sesuai dengan minatnya.

\section{DAFTAR PUSTAKA}

Akkermans, J., Paradniké, K., Van der Heijden, B. I., \& De Vos, A. (2018). The best of both worlds: The role of career adaptability and career competencies in students' well-being and performance. Frontiers in Psychology, 9. https://doi.org/10.3389/fpsyg.2018.01678

Ataç, L. O., Dirik, D., \& Tetik, H. T. (2017). Predicting career adaptability through self-esteem and social support: A research on young adults. International Journal for Educational and Vocational Guidance, 18(1), 45-61. https://doi.org/10.1007/s10775-017-9346-1

Badan Pusat Statistik. (2020). www.bps.go.id/pressrelease/2020/05/05/1672/februari-2020-tingkat-pengangguran-terbuka--tpt--sebesar-4-99-persen.html

Cai, Z., Guan, Y., Li, H., Shi, W., Guo, K., Liu, Y., Li, Q., Han, X., Jiang, P., Fang, Z., \& Hua, H. (2015). Self-esteem and proactive personality as predictors of future work self and career adaptability: An examination of mediating and moderating processes. Journal of Vocational Behavior, 86, 86-94. https://doi.org/10.1016/j.jvb.2014.10.004

Coetzee, M., \& Engelbrecht, L. (2019). How employability attributes mediate the link between knowledge workers' career adaptation concerns and their self-perceived employability. Psychological Reports, 123(4), 1005-1026. https://doi.org/10.1177/0033294119844981

Coopersmith, S. (1967). The antecedents of self esteem. Freeman and Company.

Dacre Pool, L., \& Sewell, P. (2007). The key to employability: Developing a practical model of graduate employability. Education + Training, 49(4), 277-289. https://doi.org/10.1108/00400910710754435

De Guzman, A. B., \& Choi, K. O. (2013). The relations of employability skills to career adaptability among technical school students. Journal of Vocational Behavior, 82(3), 199-207. https://doi.org/10.1016/j.jvb.2013.01.009

Denty, A., \& Aline, R. (2020, January 1). Lima Syarat 'Link and match' Pendidikan Vokasi Dan Dunia Industri. Kementerian Pendidikan dan Kebudayaan. https://www.kemdikbud.go.id/main/blog/2020/09/lima-syarat-link-and-match-pendidikan-vokasidan-dunia-industri

Gunawan, W. (2013). Pengaruh sumber-sumber efikasi diri dan efikasi diri pengambilan keputusan karir terhadap adaptabilitas karir remaja [Master's thesis]. http://lib.ui.ac.id/detail?id=20329565\&lokasi=lokal

Hakim, D., \& Fitri, E. (2019). Membangun Daya Saing Siswa SMK Melalui Employability Skill Dan Kompetensi (Studi Pada Siswa SMK Jurusan Akuntansi Se- Kota Tangerang Selatan) [Paper presentation]. In Enhancing Innovations for Sustainable Development : Dissemination of Unpam's Research Result, Universitas Pamulang. file://C:/Users/User/AppData/Local/Temp/5238-11160-1SM.pdf

Hanafi, I. (2012). Re-orientasi keterampilan kerja lulusan pendidikan kejuruan. Jurnal Pendidikan Vokasi, 2(1). https://doi.org/10.21831/jpv.v2i1.1021

Hendrianti, N. P., \& Dewinda, H. R. (2019). Konsep diri Dan dukungan sosial keluarga terhadap kematangan karir pada siswa kelas xii smk. Jurnal RAP (Riset Aktual Psikologi Universitas Negeri Padang), 10(1). https://doi.org/10.24036/rapun.v10i1.105016

Hirschi, A. (2009). Career adaptability development in adolescence: Multiple predictors and effect on sense of power and life satisfaction. Journal of Vocational Behavior, 74(2), 145-155. https://doi.org/10.1016/j.jvb.2009.01.002

Idhom, A. M. (2017, April 13). Menaker: Jumlah Tenaga Terampil Di Indonesia Cuma 57 Juta. tirto.id. https://tirto.id/menaker-jumlah-tenaga-terampil-di-indonesia-cuma-57-juta-cmGk

Indianti, W. (2015). Dukungan sosial dan regulasi diri dalam belajar untuk membangun adaptabilitas karier pada mahasiswa baru Universitas Indonesia [Doctoral dissertation]. 
http://lib.ui.ac.id/detail?id=20416090\&lokasi=lokal

Ismail, S., Ferreira, N., \& Coetzee, M. (2016). Young emerging adults' graduateness and career adaptability: Exploring the moderating role of self-esteem. Journal Of Psychology In Africa, 26(1), 1-10. https://doi.org/10.1080/14330237.2016.1148417

Istiqomah. (2016). Kematangan Karier Siswa Sekolah Menengah Kejuruan Muhammadiyah Karangmojo Ditinjau Dari Partisipasi Aktif Pada Kegiatan Ekstrakurikuler Sekolah [Skipsi]. Universitas Islam Negeri Sunan Kalijaga Yogyakarta.

Johnston, C., Luciano, E., Maggiori, C., Ruch, W., \& Rossier, J. (2013). Validation of the German version of the Career Adapt-Abilities Scale and its relation to orientations to happiness and work stress. Journal Of Vocational Behavior, 83(3), 295-304. https://doi.org/10.1016/j.jvb.2013.06.002

Johnston, C. S. (2018). A systematic review of the career adaptability literature and future outlook. Journal of Career Assessment, 26(1), 3-30. https://doi.org/10.1177/1069072716679921

Juwitaningrum, I. (2013). Program Bimbingan Karir untuk Meningkatkan Kematangan Karir Siswa SMK. Psikopedagogia Jurnal Bimbingan dan Konseling, 2(2), 132. https://doi.org/10.12928/psikopedagogia.v2i2.2580

Khurniawan, A., Mardapi, D., \& Nudira, P. (2017). Panduan Penyelenggaraan Program Pendidikan Empat Tahun Pada Sekolah Menengah Kejuruan. Jakarta: Kementerian Pendidikan dan Kebudayaan.

Kornelakis, A., \& Petrakaki, D. (2020) Embedding Employability Skills in UK higher education: Between digitalization and Marketization. Industry And Higher Education, 095042222090297. https://doi.org/10.1177/0950422220902978

McArdle, S., Waters, L., Briscoe, J., \& Hall, D. (2007). Employability during unemployment: Adaptability, career identity and human and social capital. Journal Of Vocational Behavior, 71(2), 247-264. https://doi.org/10.1016/j.jvb.2007.06.003

Munadi, S., Yuniarti, N., \& Jerusalem, M. (2018). Employability skills Lulusan SMK dan Relevansinya terhadap Kebutuhan Dunia Kerja. Jakarta: Kementerian Pendidikan dan Kebudayaan.

Orji, N. S. (2013). Assessment of employability skills development opportunities for senior secondary school chemistry students. Journal of Educational Research and Reviews, 1(2), 16-26.

Pambudi, A. (2018). Keefektivan Kelompok Psikoedukasi Teknik Modeling untuk meningkatkan Adaptabilitas Karier Melalui Self-Efficacy Pengambilan Keputusan Karier Siswa SMP Negeri 31 Purworejo (Tesis). Universitas Negeri Semarang.

Patton, W., \& Lokan, J. (2001). Perspectives on Donald Super's construct of career maturity. International Journal for Educational and Vocational Guidance, 1(1-2), 31-48.

Pusat data Dan Teknologi Informasi Kemendikbud. (2020). Kementerian Pendidikan dan Kebudayaan. https://statistik.data.kemdikbud.go.id/index.php/page/smk

Rahman, N., \& Wicaksono, D. A. (2018). Pengaruh Self-esteem terhadap Employability skills pada Mahasiswa dengan Status Kepengurusan dan Lama Waktu Mengikuti Unit Kegiatan Mahasiswa sebagai Variabel Moderator. Jurnal Psikologi Industri Dan Organisasi, X. http://url.unair.ac.id/cf758369

Rahmawati, F., \& Komariah, K. (2016). Kompetensi Teknis dan Employability skills Mahasiswa Vokasi Bidang Boga. In Professional Responsibility Pendidik dalam Menyiapkan SDM Vokasi Abad 21. Yogyakarta: PTBB FT UNY. https://journal.uny.ac.id/index.php/ptbb/article/view/30566

Ramdhani, R. N., Budiamin, A., \& Budiman, N. Adaptabilitas Karier Dewasa Awal. Jurnal Penelitian Pendidikan, 18(3), 361-370.

Restubog, S., Ocampo, A., \& Wang, L. (2020). Taking control amidst the chaos: Emotion regulation during the COVID-19 pandemic. Journal Of Vocational Behavior, 119, 103440. https://doi.org/10.1016/j.jvb.2020.103440.

Rocha, M. (2011). Transferable skills representations in a Portuguese college sample: Gender, age, adaptability and vocational development. European Journal of Psychology of Education, 27(1), 7790. https://doi.org/10.1007/s10212-011-0067-4

Rosenberg, M. (1965). Society and the adolescent self-image. Princeton University Press. 
Rosenberg, M., Schooler, C., Schoenbach, C., \& Rosenberg, F. (1995). Global self-esteem and specific self-esteem: Different concepts, different outcomes. American Sociological Review, 60(1), 141. https://doi.org/10.2307/2096350

Rosulin, R., \& Paramita, P. (2016). Hubungan antara Hardiness dengan Adaptabilitas Karier pada Siswa SMK Kelas XII. Jurnal Psikologi Pendidikan Dan Perkembangan, 5(1).

Rudolph, C., Lavigne, K., \& Zacher, H. (2017). Career adaptability: A meta-analysis of relationships with measures of adaptivity, adapting responses, and adaptation results. Journal Of Vocational Behavior, 98, 17-34. https://doi.org/10.1016/j.jvb.2016.09.002

Santrock, J. (2016). Educational psychology (5th ed.). MC Graw-Hill Education.

Savickas, M. L. (2005). The theory and practice of career construction. In S. D. Brown \& R. W. Lent (Eds.), Career development and counseling: Putting theory and research to work. John Wiley \& Sons.

Savickas, M., \& Porfeli, E. (2012). Career Adapt-Abilities Scale: Construction, reliability, and measurement equivalence across 13 countries. Journal Of Vocational Behavior, 80(3), 661-673. https://doi.org/10.1016/j.jvb.2012.01.011

Setiawan, Y. (2020). Perkuat Sinergi SMK Dan Industri. Kementerian Pendidikan dan Kebudayaan. https://smk.kemdikbud.go.id/konten/2751/perkuat-sinergi-smk-dan-industri

Syafris, N. (2017). Hubungan Antara Perilaku Cyberbullying Offending Dan Tingkat Self-esteem Pada Remaja [Skripsi]. Universitas Indonesia

Sharf, R. S. (2006). Applying Career Development Theory of Counseling. Thomson Wadsworth.

Suarta, I., Hardika, N., Sanjaya, I., \& Arjana, I. (2015). Model Authentic Self-Assessment Dalam Pengembangan Employability skills Mahasiswa Pendidikan Tinggi Vokasi. Jurnal Penelitian Dan Evaluasi Pendidikan, 19(1), 46-57. https://doi.org/10.21831/pep.v19i1.4555

Wibowo, N. (2016). Upaya Memperkecil Kesenjangan Kompetensi Lulusan Sekolah Menengah Kejuruan dengan Tuntutan Dunia Industri. Jurnal Pendidikan Teknologi Dan Kejuruan, 23(1), 45. https://doi.org/10.21831/jptk.v23i1.9354

Winkel, W. S., \& Hastuti, S. (2004). Bimbingan karir di institusi pendidikan. Media Abadi.

Yahya, M., \& Iskandar, S. (2017). Technical skills and employability skills of vocational high school students in Indonesia. Journal Of Scientific Reaserch And Studies, 4(6), 148-155. http://www.modernrespub.org/jsrs/index.html

Yudianto, F. (2020). Revolusi Industri 4.0 di Masa Pandemi Covid-19. https://duta.co/revolusi-industri-40 -di-masa-pandemi-covid-19

Zunker, V. (2012). Career counseling (7th ed.). Thomson Higher Education. 